\title{
PENGARUH BUDAYA DAN PERSEPSI MASYARAKAT NON MUSLIM TERHADAP KEPUTUSAN MENJADI NASABAH BANK SYARI'AH MANDIRI KANTOR CABANG PEMBANTU BENGKALIS
}

\author{
Anshor Wibowo, Nia Hariyati \\ Sekolah Tinggi Ilmu Ekonomi (STIE) Syariah Bengkalis \\ bowriset@gmail.com,nia.hariyati1@ymail.com
}

\begin{abstract}
This research aims to determine whether the culture and perceptions of nonMuslim communities influence the decision to become a customer at Bank Syariah Mandiri Bengkalis Sub-Branch Office partially and simultaneously. Data analysis techniques used in this study used the test of validity, reliability, hypothesis test, multiple linear regression analysis and determinant coefficient analysis. The results obtained in this study that partially cultural variables and community perceptions significantly influence the decision making to become a customer of Bank Syariah Mandiri Bengkalis Sub-Branch Office. Simultaneously there is a significant influence between culture and perceptions of non-Muslim communities on the decision to become a customer at Bank Syariah Mandiri Bengkalis SubBranch Office with an influence of $60.1 \%$.
\end{abstract}

Keywords: Culture, Perception, Decisions, Bank Syariah Mandiri.

\begin{abstract}
ABSTRAK
Penelitian ini bertujuan untuk mengetahui apakah budaya dan persepsi masyarakat non muslim berpengaruh terhadap pengambilan keputusan menjadi nasabah pada Bank Syariah Mandiri Kantor Cabang Pembantu Bengkalis secara parsial dan simultan. Teknik analisa data yang digunakan dalam penelitian ini menggunakan uji validitas, reabilitas, uji hipotesis, analisa regresi linear berganda dan analisa koefesien determinan. Hasil yang diperoleh dalam penelitian ini bahwa secara parsial variabel budaya dan persepsi masyarakat berpengaruh signifikan terhadap pengambilan keputusan menjadi nasabah Bank Syariah Mandiri Kantor Cabang Pembantu Bengkalis. Secara simultan terdapat pengaruh yang signifikan antara budaya dan persepsi masyarakat non muslim terhadap keputusan menjadi nasabah pada Bank Syariah Mandiri Kantor Cabang Pembantu Bengkalis dengan besar pengaruh $60,1 \%$.
\end{abstract}

Kata Kunci: Budaya, Presepsi, Keputusan, Bank Syariah Mandiri.

\section{PENDAHULUAN}

Perkembangan ekonomi Islam di Indonesia mengalami kemajuan yang sangat pesat. Ditandai dengan berdirinya lembaga keuangan yang berlandaskan baik dalam skala makro maupun mikro. Di Indonesia lembaga keuangan dikelompokkan dalam dua bentuk, yaitu lembaga keuangan bank dan lembaga keuangan non bank. Mengenai lembaga keuangan bank atau perbankan, menurut 
Undang Undang No. 10 Tahun 1998, perbankan adalah badan usaha yang menghimpun dana dari masyarakat dalam bentuk kredit dan atau bentuk-bentuk lainnya dalam rangka meningkatkan taraf hidup orang banyak. Dahulu sektor perbankan tersebut tidak lebih hanya sebagai fasilitator kegiatan pemerintah dan beberapa perusahaan besar, dan kini telah berubah menjadi sektor yang sangat berpengaruh bagi perekonomian. Sistem perbankan di Indonesia itu sendiri diatur dalam Undang Undang No. 7 tahun 1992 (diubah dengan UU No. 10 tahun 1998) tentang perbankan bahwa perbankan di Indonesia terdiri dari 2 (dua) jenis, yaitu Bank Umum dan Bank Perkreditan Rakyat (Ascarya 2008, 31).

Baitul mal wa tamwil atau dapat juga ditulis dengan baitul mal wa baitul tamwil secara harfiah/lughowi, baitul maal berarti rumah dana dan baitul tamwil berarti rumah usaha. Baitul maal dikembangkan berdasarkan sejarah perkembangannya, yakni dari masa Nabi sampai abad pertengahan perkembangan Islam. Dimana baitul maal berfungsi untuk mengumpulkan sekaligus mentasyarufkan dana sosial. Sedangkan baitul tamwil merupakan lembaga bisnis yang bermotif laba (Ridwan 2004, 126) berasaskan Pancasila dan UUD 45 serta berlandaskan prinsip Islam, keimanan, keterpaduan (kaffah), kekeluargaan atau koperasi, kebersamaan, kemandirian dan profesionalisme. Dengan demikian keberadaan menjadi organisasi yang legal sebagai lembaga keuangan, harus berpegang teguh pada prinsip-prinsip. Dari pengertian tersebut dapat ditarik suatu pengertian yang menyeluruh bahwa merupakan organisasi bisnis yang juga berperan sosial.

Masyarakat Kabupaten Bengkalis mayoritas masih memilih menggunakan jasa dari lembaga keuangan konvensional dibanding menggunakan jasa dari lembaga keuangan. Hal ini disebabkan oleh budaya masyarakat yang lebih dahulu mengenal lembaga keuangan konvensional dari pada lembaga keuangan, padahal masyarakat Kabupaten Bengkalis sendiri mayoritas juga beragama Islam. Kebiasaan inilah yang menyebabkan perkembangan lembaga keuangan tidak mampu menandingi lembaga keuangan konvensional dalam hal meningkatkan jumlah nasabah. Sampai saat ini kemunculan lembaga-lembaga keuangan diharapkan dapat mengubah budaya masyarakat yang menggunakan jasa lembaga keuangan konvensional dan beralih pada budaya masyarakat untuk menggunakan jasa lembaga keuangan.

Perkembangan perbankan syariah tidak hanya terliat dari sisi penambahan kuantitas saja, namun juga dari sisi sistem dan layanan. Sebelumnya pada bank umum syariah maupun unit syariah hanya boleh melayani calon nasabah di kantor cabang syariah atau kantor cabang pembantu. Namun sejak office-channeling yang didasari Peraturan BI Nomor 8/3/PBI/2006 dan berlaku efektif Mei 2007 pelayanan jasa financing, seperti pembukuan rekening, setor, transfer, kliring, dan tarik tunai bisa dilakukan di cabang bank umum yang mempunyai unit . Dengan penerapan office-channeling ini, akselerasi pertumbuhan bisa segera terealisasi.

Keberhasilan sistem keuangan syariah hingga sekarang ini tidak sematamata atas adanya dukungan regulasi pemerintah, namun juga didukung oleh kwalitas dan pelayanan yang diberikan oleh lembaga tersebut. Lembaga keuangan syariah yang dalam hal ini adalah perbankan syariah secara umum, dianggap oleh sebagian orang sebagai alternatif bagi masyarakatyang sudah jenuh dengan sistem ekonomi kapitalis, sebuah sistem ekonomi yang sudah 
lama mendunia yang selalu mengutamakan kekayaan pribadi berdampak pada ketidak merataan distribusi kekayaan sehingga banyak terjadi kesengsaraan.

Namun sisi lain, tidak sedikit masyarakat yang masih menganggap bahwa sistem ekonomi syariah hanya hadir untuk masyarakat muslim. Tidak bisa dipungkiri, paradigma fanatisme agama masih kental terlihat dalam masyarakat kita, sehingga persepsi pasar syariah sendiri hanya dipahami sebagai pasar untuk kaum muslim saja pasar yang "tertutup" untuk kalangan non muslim. Padahal, sistem bagi hasil yang merupakan salah satu elemen penting dari pasar sudah sejak lama diterapkan Negara-negara Eropa, terutama Iggris,jadi persepsi bahwa pasar konvensional selalu lebih menguntungkan dan pasar adalah "pasarnya" kaum muslim tidak tepat. Kemudian bagaimana dengan citra "Islam" dan apakah yang dapat ditawarkan untuk menarik para nasabah, sedangkan citra Islam belum menjadi daya tarik nomor satu bahkan dikalangan umat Islam sendiri.

Melihat fenomena tersebut, masyarakat mulai sadar bahwa bank-bank konvensional yang ada saat ini tidak bisa menjadi solusi terbaik dari problemproblem yang masyarakat hadapi, sehingga masyarakat melirik kembali ajaran Islam yang bebas riba. Perbankan merupakan suatu badan usaha yang fungsinya sebagai penghimpun dana dari masyarakat dan penyalur dana kepada masyarakat, yang sistem dan mekanisme kegiatan usahanya berdasarkan hukum Islam.

Tujuan dari penelitian ini adalah untuk mengetahui apakah budaya dan persepsi masyarakat non muslim berpengaruh terhadap pengambilan keputusan menjadi nasabah pada Bank Syariah Mandiri Kantor Cabang Pembantu Bengkalis secara parsial dan simultan.

\section{TELAAH LITERATUR}

\section{Budaya}

Kata kebudayaan berasal dari kata sansekerta buddhayah, yaitu bentuk jamak dari buddhi yang artinya akal. Dengan demikian kebudayaan dapat diartikan sebagai "hal-hal yang bersangkut-paut dengan akal." Dalam istilah "antropologi-budaya" pengertian "budaya" sama dengan "kebudayaan". E.B. Taylor, Bapak dan pakar dunia Antropologi Budaya, mendefinisikan budaya sebagai keseluruhan kompleks yang meliputi pengetahuan, kepercayaan, kesenian, moral, hukum, adat istiadat, dan kemampuan-kemampuan atau kebiasaankebiasaan lain yang diperoleh anggota-anggota suatu masyarakat (Martodirjdo 2004, 20).

Mudji Sutrisno dalam bukunya (Teori-Teori Kebudayaan) mengartikan budaya sebagai kebiasaan-mungkin yang sudah mengakar lama hingga dianggap berasal dari suku atau struktur genetika seseorang (Sutrisno 2003, 257). Menurut Joko Tri prasetya dalam bukunya (Ilmu Budaya Dasar) mendefinisikan budaya sebagai sebuah daya dari budi yang berupa cipta, karsa dan rasa (Prasetya 2004, 28).

Geet Hofstede dalam Culture's Consequences mendefinisikan budaya ssebagai "Collective programming of the mind." Atau collective mental program. Mental programing terdapat pada tiga level: (1) universal level of mental programming, yaitu sistem biologikal operasional manusia termasuk perilakunya yang bearsifat universal, seperti senyum dan tangis yang terjadi dimana-mana sepanjang sejarah, (2) collective level of mental programming, misalnya bahasa, 
dan (3) individual level of mental programming, misalnya kepentingan individual (Prasetya 2004, 44).

Kroeber dan Kluckhohn mengelompokkan definisi-definisi budaya menjadi 6 (enam) kelompok definisi yakni definisi yang bersifat deskriptif, historik, normatif, psikologik, struktural dan genetik. Definisi deskriptif, definisi yang masuk dalam kelompok ini cenderung menekan pada pandangan "budaya sebagai suatu totalitas yang komperhensif". Oleh karenanya definisi ini mencoba membuat daftar semua aspek kehidupan dan aktivitas manusia sebagai suatu contoh tentang apa yang dimaksud dengan budaya (Prasetya 2004, 58-59).

\section{Persepsi}

Persepsi merupakan suatu proses yang didahului oleh penginderaan, yaitu suatu proses yang diterima individu melalui alat reseptor yaitu alat indera. Proses penginderaan ini tidak terlepas dari proses persepsi. Alat indera merupakan penghubung antara individu dengan dunia eksternal. Gibson mengemukakan bahwa persepsi adalah proses kognitif yang dipergunakan oleh individu untuk menafsirkan dan memahami dunia sekitarnya. Dengan kata lain, persepsi mencangkup penerimaan stimulus yang diorganisasikan, dan penerjemahan atau penafsiran stimulus yang diorganisasikan dengan cara yang dapat mempengaruhi perilaku dan pembentukan sikap (Martodirjdo 2004, 17). Pengertian persepsi menurut Joseph A. Devito, persepsi adalah proses menjadi sadar akan banyaknya stimulus yang mempengaruhi indra kita (Sunaryo 2002, 40).

Menurut Hamka proses terjadinya persepsi melalui tahap-tahap sebagai berikut: Tahap pertama, merupakan tahap yang dikenal dengan nama proses kealaman atau proses fisik, yaitu proses ditangkapnya suatu stimulus (objek) oleh panca indera. Tahap kedua, merupakan tahap yang dikenal dengan proses fisiologis, yaitu proses diteruskanya stimulus atau objek yang telah diterima alat indera melalui syaraf-syaraf sensoris ke otak. Tahap ketiga merupakan proses yang dikenal dengan nama proses psikologis, yaitu proses dalam otak, sehingga individu mengerti, menyadari, menafsirkan dan menilai objek tersebut. Tahap keempat, merupakan hasil yang diperoleh dari proses persepsi yaitu berupa tanggapan, gambaran atau kesan (Hamka 2002, 81).

Di samping itu ada faktor lain yang dapat mempengaruhi proses persepsi, antara lain: (1) Faktor internal, Individu sebagai faktor internal saling berinteraksi dalam individu mengadakan persepsi. Mengenai keadaan individu yang dapat mempengaruhi hasil persepsi datang dari dua sumber, yaitu berhubungan dengan segi kejasmanian dan segi psikologis. Bila sistem fisiologis terganggu, hal tersebut akan berpengaruh dalam persepsi seseorang. Sedangkan segi psikologis yaitu antara lain mengenai pengalaman, perasaan, kemampuan berpikir, kerangka acuan, dan motivasi akan berpengaruh pada seseorang dalam mengadakan persepsi. (2) Faktor eksternal, stimulus, agar stimulus dapat dipersepsi, maka stimulus harus cukup kuat. Kejelasan stimulus akan banyak berpengaruh dalam persepsi. Stimulus yang kurang jelas akan berpengaruh dalam ketepatan persepsi. Bila stimulus berwujud benda bukan manusia, maka ketepatan persepsi lebih terletak pada individu yang mengadakan persepsi, karena benda yang dipersepsi tersebut tidak ada usaha untuk mempengaruhi yang mempersepsi. Lingkungan atau situasi khususnya yang melatarbelakangi stimulus juga akan berpengaruh dalam persepsi bila obyek persepsi adalah manusia. Obyek dan lingkungan yang 
melatarbelakangi obyek merupakan kesatuan yang sulit dipisahkan. Obyek yang sama dengan situasi sosial yang berbeda dapat menghasilkan persepsi yang berbeda (Walgito 1990, 46-47).

\section{Keputusan}

Johannes Supranto mendefinisikan mengambil atau membuat keputusan berarti memilih satu diantara sekian banyak alternatif (Supranto 2005, 1). Dalam tahap evaluasi konsumen membentuk preferensi antar merk dalam kumpulan pilihan. Konsumen mungkin juga membentuk maksud untuk membeli merk yang paling disukai. Dalam melaksanakan maksud pembelian, konsumen dapat membentuk lima sub keputusan merk, penyaluran, kuantitas, waktu, dan metode pembayaran (Kotler 2008, 258).

Keputusan untuk membeli yang diambil oleh pembeli itu sebenarnya merupakan kumpulan dari sejumlah keputusan. Setiap keputusan membeli mempunyai suatu struktur sebanyak tujuh komponen, yaitu: keputusan tentang jenis produk, keputusan tentang bentuk produk, keputusan tentang merk, keputusan tentang penjualan, keputusan tentang jumlah produk, keputusan tentang waktu pembelian, keputusan tentang cara pembayaran. Dalam suatu pembelian barang keputusan yang diambil tidak selalu berurutan seperti di muka. Pada situasi pembelian seperti penyelesaian masalah ekstensif, keputusan yang diambil dapat bermula dari keputusan tentang penjual karena penjual dapat membantu merumuskan perbedaan-perbedaan di antara bentuk-bentuk dan merk produk (Swasta 2005, 118-119).

Menurut Kotler faktor-faktor yang mempengaruhi perilaku konsumen dalam mengambil keputusan adalah: (1) Faktor Budaya, yaitu meliputi budaya (penentu keinginan dan perilaku yang mendasar), sub-budaya (bangsa, agama, suku, daerah), dan kelas sosial. (2) Faktor Sosial, perilaku seorang konsumen dipengaruhi faktor-faktor sosial seperti kelompok acuan, keluarga, peran dan status. (3) Faktor Pribadi, merupakan faktor pribadi (usia, tahap siklus hidup, pekerjaan, keadaan ekonomi, gaya hidup, kepribadian dan konsep-diri pembeli). (4) Faktor Psikologis, faktor psikologi utama yaitu motivasi, persepsi, pengetahuan, serta keyakinan dan pendirian (Efendi 2009, 25).

\section{Nasabah}

Menurut Kamus Perbankan, nasabah adalah orang atau badan yang mempunyai rekening simpanan atau pinjaman pada bank (Djaslim 2002, 7). Pada tahun 1998 melalui Undang-Undang Nomor 10 Tahun 1998 diintroduksilah rumusan masalah nasabah dalam pasal 1 angka 16, yaitu pihak yang menggunakan jasa bank. Rumusan ini kemudian diperinci pada angka berikutnya, sebagai berikut: Nasabah penyimpan dana adalah nasabah yang menempatkan dananya di bank dalam bentuk simpanan berdasarkan perjanjian bank dengan nasabah yang bersangkutan. (Pasal 1 angka 17 Undang-Undang Nomor 10 Tahun 1998). Nasabah debitur adalah nasabah yang memperoleh fasilitas kredit atau pembiayaan berdasarkan prinsip atau yang dipersamakan dengan itu berdasarkan perjanjian bank dengan nasabah yang bersangkutan (Pasal 1 angka 18 UndangUndang Nomor 10 Tahun 1998) (Widiyono 2006, 30).

Nasabah bank terdiri dari orang yang telah dewasa dan orang yang belum dewasa. Nasabah orang dewasa hanya diperbolehkan untuk nasabah kredit dan 
atau nasabah giro. Sedangkan nasabah simpanan dan atau jasa-jasa bank lainnya dimungkinkan orang yang belum dewasa, misalnya nasabah tabungan dan atau nasabah lepas (working customer) untuk transfer dan sebagainya. Terhadap perjanjian yang dibuat antara bank dengan nasabah yang belum dewasa tersebut telah disadari konsekuensi hukum yang diakibatkannya. Konsekuensi hukum tersebut adalah tidak dipenuhinya salah satu unsur sahnya perjanjian seperti yang termuat dalam pasal $1320 \mathrm{KUH}$ Perdata, maka perjanjian tersebut dapat dibatalkan, artinya perjanjian tersebut dapat dibatalkan oleh pihak yang dapat mewakili anak yang belum dewasa itu, yaitu orang tua atau walinya melalui acara gugatan pembatalan. Dengan kata lain, selama orang tua atau wali dari orang yang belum dewasa tersebut tidak melakukan gugatan, maka perjanjian tersebut tetap berlaku dan mengikat terhadap para pihak. Nasabah kredit dan rekening giro bisaaanya diwajibkan bagi nasabah yang telah dewasa. Hal ini disebabkan karena resiko bank yang sangat besar jika dalam pemberian kredit dan atau pembukaan rekening giro diperbolehkan bagi nasabah yang belum dewasa.

Untuk nasabah berupa badan, perlu diperhatikan aspek legalitas dari badan tersebut serta kewenangan bertindak dari pihak yang berhubungan dengan bank. Hal ini berkaitan dengan aspek hukum perseorangan. Berkaitan dengan kewenangan bertindak bagi nasabah yang bersangkutan, khususnya bagi "badan", termasuk apakah untuk perbuatan hukum tersebut perlu mendapat persetujuan dari komisaris atau Rapat Umum Pemegang Saham (RUPS) agar diperhatikan anggaran dasar dari badan yang bersangkutan. Subjek hukum yang berbentuk badan, tidak otomatis dapat berhubungan dengan bank. Untuk dapat berhubungan dengan bank, harus juga dilihat peraturan perundang-undangan yang berlaku dan bagaimana ketentuan internal yang berlaku pada bank yang bersangkutan (Widiyono 2006, 24).

Dari penjelasan literatur di atas maka dapat dihimpun hipotesis sebagai berikut: hipotesis pertama, budaya masyarakat non muslim berpengaruh signifikan terhadap pengambilan keputusan menjadi nasabah pada Bank Mandiri Syariah Kantor Cabang Pembantu Bengkalis. Hipotesis kedua, persepsi masyarakat non muslim berpengaruh signifikan terhadap pengambilan keputusan menjadi nasabah pada Bank Mandiri Syariah Kantor Cabang Pembantu Bengkalis. Hipotesis ketiga, budaya dan persepsi masyarakat non muslim berpengaruh signifikan secara simultan terhadap pengambilan keputusan menjadi nasabah pada Bank Mandiri Syariah Kantor Cabang Pembantu Bengkalis.

\section{METODE PENELITIAN}

Penelitian ini dilakukan di Bank Syariah Mandiri Kantor Cabang Pembantu Bengkalis, Kabupaten Bengkalis yang terletak di Jalan Hang Tuah. Populasi dari penelitian ini adalah nasabah non muslim Bank Syariah Mandiri Kantor Cabang Pembantu Bengkalis dengan jumlah populasi sebanyak 100 orang nasabah non muslim. Teknik sampel yang digunakan adalah Non Probability Sampling dengan jenis sampel jenuh, dimana penarikan sampel berdasarkan atas ciri-ciri, sifat-sifat atau karakteristik tertentu, yang merupakan ciri-ciri populasi. Jadi sampel dalam penelitian ini adalah sebanyak 100 orang nasabah non muslim Bank Syariah Mandiri Kantor Cabang Pembantu Bengkalis. Jenis data yang digunakan adalah data kuantitatif. Teknik pengumpulan data dengan 
menggunakan metode angket (questionnaire), dokumentasi, observasi dan studi pustaka. Teknik analisis data menggunakan deskriptif kuantitatif dengan melakukan pengujian uji validitas, uji reliabilitas, uji normalitas, uji heteroskedastisitas, uji multikolinearitas, uji regresi linear berganda, uji hipotesis dan koefisien determinasi.

\section{HASIL DAN PEMBAHASAN PENELITIAN}

\section{Data Responden}

Responden dalam penelitian ini adalah nasabah Bank Syariah Mandiri dengan jumlah 100 orang responden.

Tabel 1 Karakteristik Responden Berdasarkan Jenis Kelamin

\begin{tabular}{lcc}
\hline \multicolumn{1}{c}{ Kategori } & Frekuensi (orang) & Presentasi (\%) \\
\hline Laki-laki & 70 & 70 \\
Perempuan & 30 & 30 \\
\hline \multicolumn{1}{c}{ Jumlah } & $\mathbf{1 0 0}$ & $\mathbf{1 0 0}$ \\
\hline Sumber: olahan peneliti & &
\end{tabular}

\section{Uji Validitas}

Tabel 2 Uji Validitas Variabel Budaya Masyarakat Non Muslim (X1)

\begin{tabular}{cccc}
\hline Item & $\mathbf{r}_{\text {hitung }}$ & $\mathbf{r}_{\text {tabel }}$ & Keterangan \\
\hline X1.1 & 0,782 & 0,254 & Valid \\
X1.2 & 0,614 & 0,254 & Valid \\
X1.3 & 0,680 & 0,254 & Valid \\
X1.4 & 0,753 & 0,254 & Valid \\
X1.5 & 0,626 & 0,254 & Valid \\
X1.6 & 0,599 & 0,254 & Valid \\
\hline \multicolumn{2}{l}{ Sumber: olahan peneliti } & &
\end{tabular}

Berdasarkan tabel 2 di atas dapat dijelaskan bahwa item setiap pertanyaan pada penelitian ini dinyatakan valid, dalam menentukan validitas peneliti membandingkan antara $r_{\text {hitung }}$ dengan $r_{\text {tabel }}$ dimana pengambilan keputusan ditentukan apabila $r_{\text {hitung }}>r_{\text {tabel }}$ maka item dikatakan valid. Seperti tabel 7 diatas nilai tiap item yang nilai $r_{\text {hitung }}$ lebih besar dari nilai $r_{\text {table }}$ yaitu sebesar 0.254, maka item kuesioner X1 dinyatakan valid secara keseluruhan.

Tabel 3 Uji Validitas Variabel Presepsi Masyarakat Non Muslim (X2)

\begin{tabular}{cccc}
\hline Item & $\mathbf{r}_{\text {hitung }}$ & $\mathbf{r}_{\text {tabel }}$ & Keterangan \\
\hline X2.1 & 0,793 & 0,254 & Valid \\
X2.2 & 0,802 & 0,254 & Valid \\
X2.3 & 0,865 & 0,254 & Valid \\
X2.4 & 0,702 & 0,254 & Valid \\
X2.5 & 0,865 & 0,254 & Valid \\
X2.6 & 0,519 & 0,254 & Valid \\
\hline
\end{tabular}

Sumber: olahan peneliti 
Berdasarkan tabel 3 di atas dapat dijelaskan bahwa item setiap pertanyaan pada penelitian ini dinyatakan valid, dalam menentukan validitas peneliti membandingkan antara $r_{\text {hitung }}$ dengan $r_{\text {tabel }}$ dimana pengambilan keputusan ditentukan apabila $r_{\text {hitung }}>r_{\text {tabel }}$ maka item dikatakan valid. Seperti tabel 8 diatas nilai tiap item yang nilai $r_{\text {hitung }}$ lebih besar dari nilai $r_{\text {tabel }}$ yaitu sebesar 0.254, maka item kuesioner X2 dinyatakan valid secara keseluruhan.

Tabel 4 Uji Validitas Variabel Keputusan Menjadi Nasabah (Y)

\begin{tabular}{cccc}
\hline Item & $\mathbf{r}_{\text {hitung }}$ & $\mathbf{r}_{\text {tabel }}$ & Keterangan \\
\hline Y.1 & 0,799 & 0,254 & Valid \\
Y.2 & 0,788 & 0,254 & Valid \\
Y.3 & 0,699 & 0,254 & Valid \\
Y.4 & 0,566 & 0,254 & Valid \\
Y.5 & 0,749 & 0,254 & Valid \\
\hline \multicolumn{4}{l}{ Sumber: olahan peneliti }
\end{tabular}

Berdasarkan tabel 4 di atas dapat dijelaskan bahwa item setiap pertanyaan pada penelitian ini dinyatakan valid, dalam menentukan validitas peneliti membandingkan antara $r_{\text {hitung }}$ dengan $r_{\text {tabel }}$ dimana pengambilan keputusan ditentukan apabila $r_{\text {hitung }}>r_{\text {tabel }}$ maka item dikatakan valid. Seperti tabel 9 diatas nilai tiap item yang nilai $r_{\text {hitung }}$ lebih besar dari nilai $r_{\text {tabel }}$ yaitu sebesar 0.254 , maka item kuesioner Y dinyatakan valid secara keseluruhan.

\section{Uji Reliabilitas}

\section{Tabel 5 Uji Reabilitas}

\begin{tabular}{ccl}
\hline Variabel & $\begin{array}{c}\text { Cronbach's } \\
\text { Alpha }\end{array}$ & Keterangan \\
\hline X1 & 0,777 & Reliabel \\
X2 & 0,862 & Reliabel \\
Y & 0,709 & Reliabel \\
\hline \multicolumn{2}{l}{ Sumber: output SPSS }
\end{tabular}

Berdasarkan tabel 5 di atas, nilai Cronbach's Alpha sebesar 0,777 untuk variabel budaya non muslim $\left(\mathrm{X}_{1}\right)$ lebih besar dari 0,60 maka dapat dikatakan reliabel. Nilai Cronbach's Alpha sebesar 0,862 untuk variabel presepsi masyarakat non muslim (X2) lebih besar dari 0,60 maka dapat dikatakan reliabel. Nilai Cronbach's Alpha sebesar 0,709 untuk variabel pengambilan keputusan manjadi nasabah (Y) lebih besar dari 0,60 maka dapat dikatakan reliabel.

\section{Uji Normalitas}

Berdasarkan gambar 1 diatas maka dapat dilihat dengan nilai skewnses berada di titik sumbu ke 4 dan sumbu (-4). pada sumbu $X$ sebagai sumbu skweness dan pada sumbu Y kurtosis berada pada nilai 3. Hal ini menandakan tingkat simetris antara skweness dan kurtosis memiliki keseimbangan dimana grafik berbentuk simetris lonceng. 


\section{Gambar 1 Histogram}

Histogram

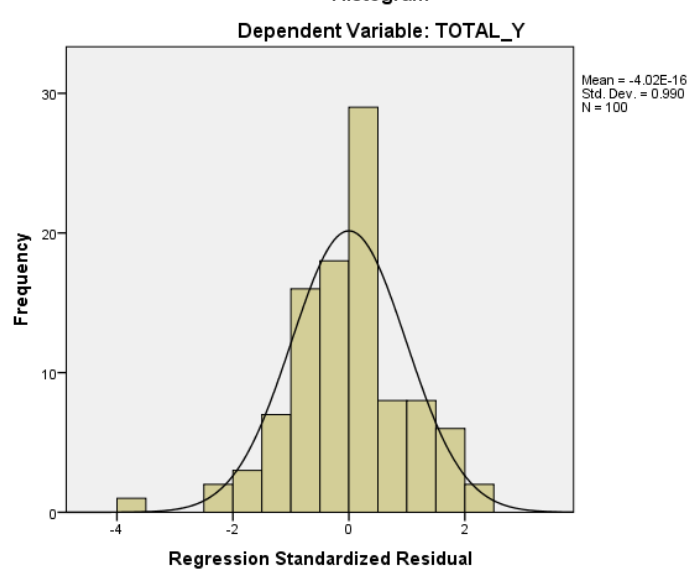

Sumber: output SPSS

\section{Gambar 2 P-Plot Variabel Budaya Masyarakat Non Muslim (X1)}

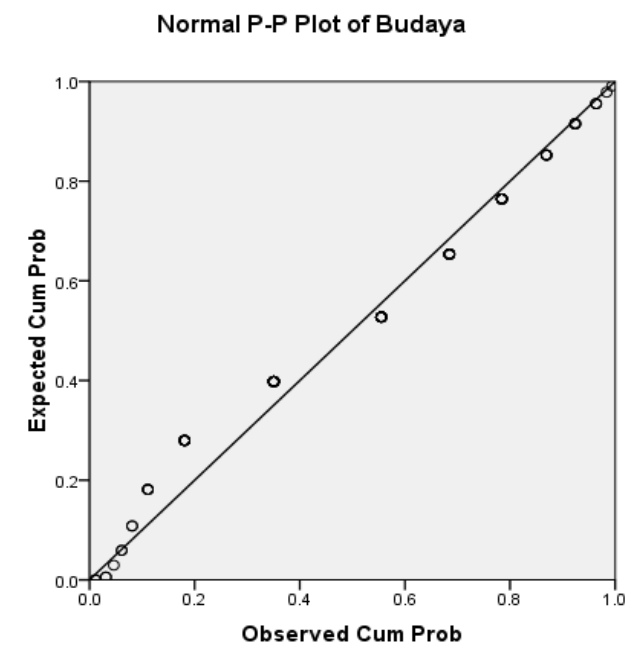

Sumber: output SPSS

Berdasarkan gambar 2 di atas data pada variabel X1, dinyatakan terdistribusi normal. Suatu variabel dikatakan normal jika gambar distribusi dengan titik-titik data yang menyebar disekitar garis diagonal dan penyebaran titik-titik data searah mengikuti garis diagonal. 


\section{Gambar 3 P-Plot Variabel Persepsi Masyarakat Non Muslim (X2)}

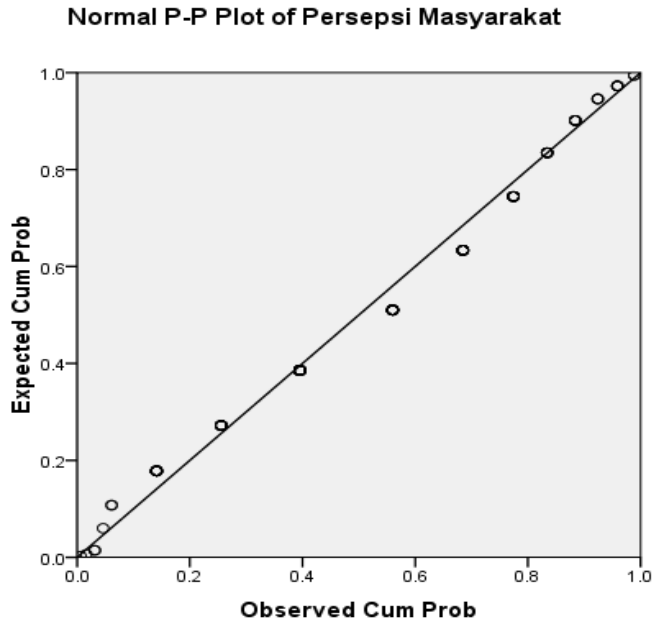

Sumber: output SPSS

Berdasarkan gambar 3 di atas data pada variabel X2, dinyatakan terdistribusi normal.

\section{Gambar 4 P-Plot Variabel Keputusan Menjadi Nasabah (Y)}

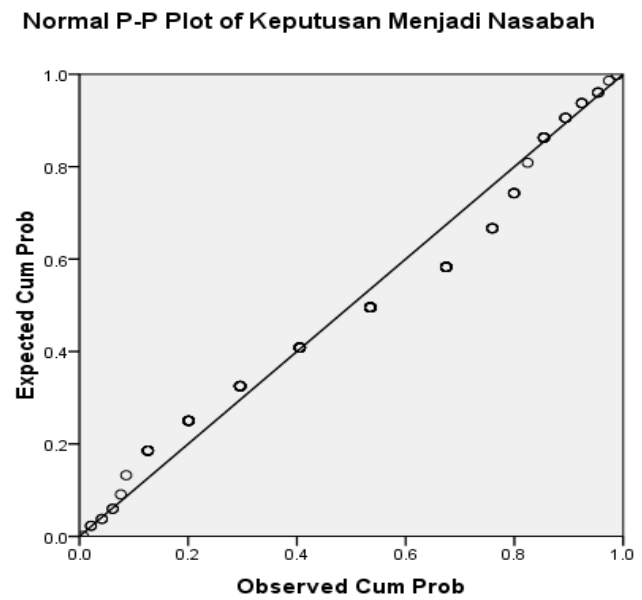

Sumber: output SPSS normal

Berdasarkan gambar 4 di atas data pada variabel $\mathrm{Y}$, dinyatakan terdistribusi

\section{Uji Heteroskedastisitas}

Dari gambar 5 di bawah dapat dilihat bahwa tidak terdapat heteroskedastisitas karena penyebaran titik-titik data tidak berpola, titik-titik data menyebar di atas dan di bawah atau disekitar angka 0 dan titik-titik data tidak mengumpul hanya di atas atau di bawah saja. 


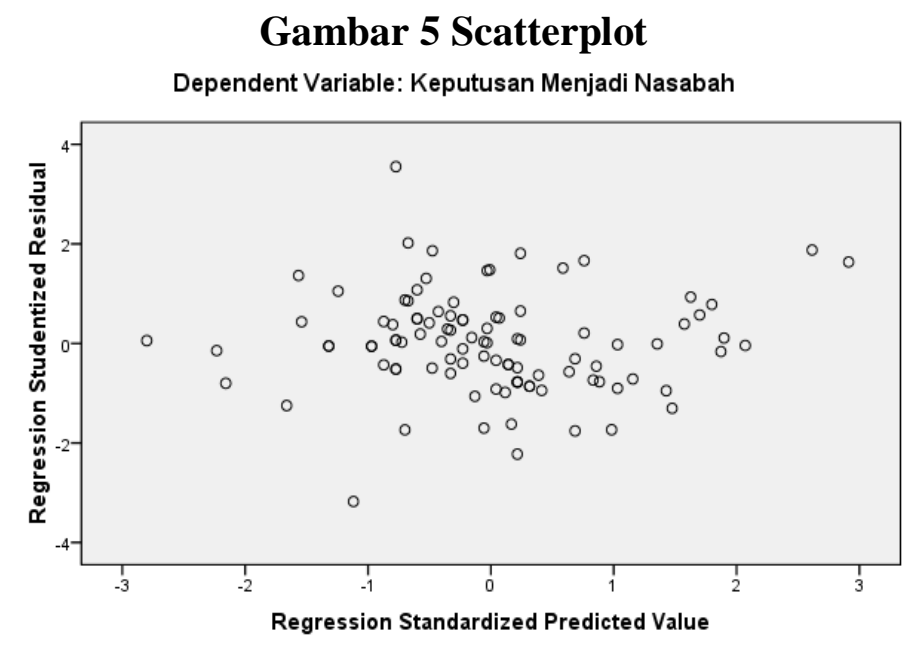

Sumber: output SPSS

\section{Uji Multikolinearitas}

Tabel 6 Uji Multikolinearitas

\begin{tabular}{lcl}
\hline \multicolumn{1}{c}{ Variabel } & Nilai VIF & \multicolumn{1}{c}{ Keterangan } \\
\hline Budaya (X1) & 1,114 & $\begin{array}{l}\text { Terbebas dari asumsi klasik } \\
\text { multikolinearitas } \\
\text { Persepsi Masyarakat }\end{array}$ \\
$\begin{array}{l}\text { (X2) } \\
\text { Terbebas dari asumsi klasik } \\
\text { multikolinearitas }\end{array}$ \\
\hline
\end{tabular}

Sumber: olahan peneliti

Berdasarkan tabel 6 di atas nilai VIF adalah 1,114 untuk semua variabel, hasil ini berarti bebas dari asumsi klasik multikolinearitas, karena hasilnya lebih kecil dari 10.

\section{Uji Regresi Linier Berganda}

\begin{tabular}{|c|c|c|c|c|c|c|}
\hline \multicolumn{7}{|c|}{ Tabel 7 Coefficients ${ }^{\mathrm{a}}$} \\
\hline & \multirow[t]{2}{*}{ Model } & \multicolumn{2}{|c|}{$\begin{array}{l}\text { Unstandardized } \\
\text { Coefficients }\end{array}$} & \multirow{2}{*}{$\begin{array}{c}\text { Standardized } \\
\text { Coefficients } \\
\text { Beta }\end{array}$} & \multirow[t]{2}{*}{$T$} & \multirow[t]{2}{*}{ Sig. } \\
\hline & & $\boldsymbol{B}$ & Std. Error & & & \\
\hline \multirow[t]{3}{*}{1} & (Constant) & 4,363 & 1,132 & & 3,854 & ,000 \\
\hline & $\mathrm{X} 1$ &, 558 & ,091 &, 555 & 6,106 & 000 \\
\hline & $\mathrm{X} 2$ & 209 & ,068 & 280 & 3,080 & ,003 \\
\hline
\end{tabular}

Sumber: output SPSS

Dari tabel 7 diatas diperoleh persamaan regresi sebagai berikut: $\mathrm{Y}=$ 4,363+0,558 X1 + 0,209 X2, nilai konstanta sebesar 4,363 satu satuan menyatakan bahwa jika dalam keadaan konstan atau tetap budaya dan persepsi masyarakat maka keputusan menjadi nasabah bernilai 4,363 satu satuan. Koefisien regresi X1 sebesar 0,558 menyatakan bahwa setiap penambahan 1 satuan tingkat budaya, budaya akan meningkatkan keputusan menjadi nasabah sebesar 0,558 satu satuan. Dan sebaliknya, jika budaya menurunkan 1 satuan tingkat budaya, 
maka keputusan menjadi nasabah akan turun sebesar 0,558 satu satuan dengan anggapan X2 tetap. Koefisien regresi X2 sebesar 0,209 satu satuan menyatakan bahwa setiap penambahan 1 satuan persepsi masyarakat, persepsi masyarakat akan meningkatkan keputusan menjadi nasabah sebesar 0,209 satu satuan. Dan sebaliknya, jika persepsi masyarakat menurunkan 1 tingkat persepsi masyarakat, maka keputusan menjadi nasabah akan turun sebesar 0,209 satu satuan dengan anggapan X1 tetap.

\section{Uji Hipotesis}

Hipotesis pertama "budaya masyarakat non muslim berpengaruh signifikan terhadap pengambilan keputusan menjadi nasabah pada Bank Mandiri Syariah Kantor Cabang Pembantu Bengkalis". Dalam tabel 7 coefficients diperoleh nilai sig. sebesar 0,000 dibandingkan dengan taraf signifikan $(\alpha=5 \%)$ 0,05 maka Sig. $<\alpha=0,000<0.05$. Karena nilai sig. $<\alpha$ maka dikatakan hipotesis diterima.

Hipotesis yang kedua "persepsi masyarakat non muslim berpengaruh signifikan terhadap pengambilan keputusan menjadi nasabah pada Bank Mandiri Syariah Kantor Cabang Pembantu Bengkalis". Dalam tabel 7 coefficients diperoleh nilai sig. sebesar 0,003 dibandingkan dengan taraf signifikan $(\alpha=5 \%)$ 0,05 maka Sig. $<\alpha=0,003<0.05$. Karena nilai sig. $<\alpha$ maka dikatakan Hipotesis diterima.

Hipotesis yang ketiga "budaya dan persepsi masyarakat non muslim berpengaruh signifikan secara simultan terhadap pengambilan keputusan menjadi nasabah pada Bank Mandiri Syariah Kantor Cabang Pembantu Bengkalis”. Untuk menguji variabel budaya masyarakat non muslim (X1) dan persepsi masyarakat non muslim (X2) yang secara signifikan bersama-sama mempengaruhi keputusan menjadi nasabah maka dilakukan pengujian dengan menggunakan uji $\mathrm{F}$. Berdasarkan nilai sig pada tabel anova (output SPPS) sebesar 0,000, dibandingkan dengan taraf signifikansi $(\alpha)=0,05(5 \%)$ atau: Sig. $<\alpha$; $0,000<0,05$, karena nilai sig lebih kecil dibandingkan $a$, maka dapat dikatakan bahwa hipotesis diterima.

\section{Uji Koefisien Determinasi}

Untuk linier berganda sebaiknya menggunakan $R$ Square yang sudah disesuaikan (Adjusted $R$ Square), karena disesuaikan dengan jumlah variabel independent yang digunakan (Sujianto 2009, 71).

Tabel 8 Model Summary

\begin{tabular}{ccccc|}
\hline Model & $\boldsymbol{R}$ & $\boldsymbol{R}$ Square & $\begin{array}{c}\text { Adjusted } \boldsymbol{R} \\
\text { Square }\end{array}$ & $\begin{array}{c}\text { Std. Error of the } \\
\text { Estimate }\end{array}$ \\
\hline 1 &, $781^{\mathrm{a}}$ &, 609 &, 601 & 1,20967 \\
$\begin{array}{l}\text { a. Predictors: (Constant), Persepsi Masyarakat, Budaya } \\
\text { Sumber: output SPSS }\end{array}$ & &
\end{tabular}

Nilai $R$ Square atau koefisien determinasi berkisar antara 0 sampai 1. Dalam tabel 15 diatas, $R$ Square sebesar 0,609. Nugroho menyatakan, untuk regresi linier berganda sebaiknya menggunakan $R$ Square yang sudah disesuaikan atau tertulis Adjusted $R$ Square, karena disesuaikan dengan jumlah variabel independen yang digunakan. Nilai Adjusted $R$ Square adalah sebesar 0,601 atau 
60,1\%. Artinya budaya dan persepsi masyarakat memiliki pengaruh sebesar $60,1 \%$ terhadap keputusan menjadi nasabah pada Bank Syariah Mandiri Kantor Cabang Pembantu Bengkalis dan sisanya 39,9\% dijelaskan oleh variabel lain.

\section{KESIMPULAN}

Berdasarkan data yang diperoleh dan diolah peneliti dapat disimpulkan bahwa budaya berpengaruh signifikan terhadap pengambilan keputusan menjadi nasabah Bank Syariah Mandiri Kantor Cabang Pembantu Bengkalis. Kemudian persepsi masyarakat berpengaruh signifikan terhadap pengambilan keputusan menjadi nasabah Bank Syariah Mandiri Kantor Cabang Pembantu Bengkalis. Secara simultan budaya dan persepsi masyarakat berpengaruh signifikan terhadap pengambilan keputusan menjadi nasabah Bank Syariah Mandiri Kantor Cabang Pembantu Bengkalis dengan besar pengaruh 60,1\%.

\section{DAFTAR PUSTAKA}

Arikunto, Suharsimi. 1998. Prosedur Penelitian Suatu Pendekatan Praktek. Jakarta: Rineka Cipta.

Arikunto, Suharsimi. 2002. Prosedur Penelitian Suatu Pendekatan Praktek. Jakarta: Rineka Cipta.

Arikunto, Suharsimi. 2006. Prosedur Penelitian Suatu Pendekatan Praktek, Cet.13. Jakarta: Rineka Cipta.

Ascarya. 2008. Akad dan Produk Bank. Jakarta: PT. Raja Grafindo Persada.

Bungin, Burhan. 2005. Metodologi Penelitian Kuantitatif. Jakarta: Prenada Media.

Departemen Agama Republik Indonesia. 1998. Al- Qur`an dan Terjemahnya. Jakarta: Departemen Agama Islam.

Djaslim, Saladin. 2002. Manajemen Pemasaran. Bandung: PT. Linda Karya.

Efendi, Lutfi. 2009. "Analisis Faktor-Faktor yang Mempengaruhi Keputusan Nasabah pada Bank Muamalat Malang". Skripsi.

Eryana. 2017. "Pengaruh Budaya Organisasi Dan Komitmen Organisasi Terhadap Motivasi Kerja Karyawan Rumah Sakit Lancang Kuning Pekanbaru". IQTISHADUNA: Jurnal Ilmiah Ekonomi Kita 6 (1), 66-81.

Hadi, Sutrino. 2000. Metodologi Research Jilid 1. Yogyakarta: Andi Offset.

Hadjar, Ibnu. 1996. Dasar-dasar Metodologi Kuantitatif Dalam Pendidikan. Jakarta: PT. Raja Grafindo Persada.

Hamka, Muhammad. 2002. "Hubungan antara Persepsi Terhadap Pengawasan Kerja dengan Motivasi Berprestasi”. Skripsi. Surakarta: Universitas Muhammadiyah Fakultas Psikologi.

Hartono. 2008. SPSS 16.0 Analisa Data Statistik dan Penelitian. Yogyakarta: Pustaka Pelajar.

Kementrian Koperasi dan UKM Republik Indonesia. 2013. Modul Pengawasan Penerapan Prinsip-prinsip. Modul Pelatihan Pendirian dan Pengembangan KJKS.

Kotler, Philip. 2002. Marketing Managemen, Millenium Edition North Western University. New Jersey: Prentice Hall Inc. 
Kotler, Philip. 2008. Manajemen Pemasaran. Yogyakarta: PT. Gelora Aksara Pratama.

Martodirjdo, Haryo S. 2004. Pemahaman Lintas Budaya. Jakarta: PT. Raja Grafindo.

Muhammad. 2004. Etika Bisnis Islami. Yogyakarta: UPP-AMP YKPN.

Muhammad. 2005. Lembaga-Lembaga Keuangan Umat Kontemporer. Yogyakarta: UII Press.

Muhammad. 2007. Lembaga Ekonomi Cet Pertama. Yogyakarta: Ghara Ilmu.

Nurhartati, Fitri. 2008. Koperasi. Surakarta: PT. Era Intermedia.

Prasetya, Joko Tri. 2004. Ilmu Budaya Dasar. Jakarta: MKDU.

Rachmad, Dedy. 2013. "Pemilihan Institusi Perbankan Syariah Di Kalangan Masyarakat Muslim Indonesia". IQTISHADUNA: Jurnal Ilmiah Ekonomi Kita 2 (1), 396-403.

Ridwan, Muhammad. 2004. Manajemen Baitul Mal Wa Tamwil. Yogyakarta: UII Pres.

Sobirin, Achmad. 2007. Budaya Organisasi. Yogyakarta: UPP-AMP YKPN.

Sudjana, Nana. 2001. Tuntunan Penyusunan Karya Ilmiah Makalah-Skripsi-TesisDisertasi, Bandung: Sinar Baru Algasindo.

Sugiono. 2006. Statistik Untuk Penelitian. Bandung: Alfabeta.

Sugiyono. 2005. Metode Penelitian Bisnis. Jakarta: Alfabeta.

Sujianto, Agus Eko. 2009. Aplikasi Statistik dengan SPSS 16.0. Jakarta: Prestasi Pustaka Publisher.

Sukandarrumidi. 2006. Metode Penelitian Petunjuk Praktis untuk Penelitian Pemula. Yogyakarta: Gadjah Mada University Press.

Sunaryo. 2002. Psikologi Untuk Keperawatan. Jakarta: EGC.

Supranto, J. 2005. Teknik Pengambilan Keputusan. Jakarta: PT. Rineka Cipta.

Suryabrata, Sumadi. 2003. Metodologi Penelitian. Jakarta: PT. Grafindo Persada. Sutrisno, Mudji. 2003. Teori-Teori Kebudayaan. Jakarta: UPP-AMP YKPN.

Swasta DH. Basu. 2005. Manajemen Pemasaran Modern. Yogyakarta: Liberty Yogyakarta.

Syarifudin, Arif. 2011. Manajemen Keuangan. Bengkalis: STAIN Bengkalis.

Tanzeh, Ahmad. 2009. Pengantar Metodologi Penelitian. Yogyakarta: Teras.

Tim Penyusun Kamus Pusat Bahasa. 2003. Kamus Besar Bahasa Indonesia, Ed. III. Cet. Ke-3. Yogyakarta: Kanisius.

Usman, Husain. 2008. Metodologi Penetilitian Sosial. Jakarta: Bumi Aksara. Walgito, Bimo. 1990. Pengantar Psikologi Umum. Yogyakarta: Andi Offset.

Widiyono, Thy. 2006. Aspek Hukum Operasional Transaksi Produk Perbankan Di Indonesia. Bogor: Ghalia Indonesia.

Zumairi, Lina. 2012. "Pengaruh Status Sosial Keluarga dan Prestasi Sekolah Terhadap Motivasi Berwira Usaha Siswa Kelas XI SMK Muhammadiyah 1 Trenggalek". Skripsi. 